\title{
Obesity, Metabolic Syndrome, and Cardiovascular Disease
}

\author{
YACINE AGGOUN \\ Department of Paediatrics, Paediatric Cardiology Unit, University Hospital of Geneva, 1211 Geneva, Switzerland
}

\begin{abstract}
Early childhood overweight and obesity have alarmingly increased over the years. Adulthood obesity is a well demonstrated significant independent predictor of cardiovascular risk (CVR) and/or mortality, which predisposes to the major components of metabolic syndrome (MS). Evidence of MS in obese children has been also reported associated with biochemical and inflammatory factors that affect vascular physiologic function. Assessment of vascular function can be measured noninvasively in children allowing early detection of endothelial dysfunction and severe increase of arterial stiffness before clinical manifestations of atherosclerosis. Impairment of endothelial function related to the severity of obesity and to the degree of insulin resistance is considered as a condition that confers a premature atherogenicity status and is linked to adult conventional cardiovascular risk factors. Adipose tissue factors that interfere with insulin action and endothelial cell function have also been identified as major precursors of CVR factors. The metabolic and cardiovascular consequences of childhood obesity are well demonstrated and have a major impact on the development of atherosclerosis and lifetime CVR. The development of programs involving both diet and exercise for children with overt overweight/obesity appears to be essential to improve vascular function and metabolic disorders. Such interventions should be complemented by a primary prevention against childhood obesity. (Pediatr Res 61: 653-659, 2007)
\end{abstract}

A $\mathrm{n}$ alarming increase in overweight has been noticed amongst children and adolescents. For example, in the United States of America as part of the National Health and Nutritional Examination Survey (NHANES) between 1999 to $2002,31 \%$ of children and adolescents aged 6 to 19 y were at risk for overweight or obesity and $16.0 \%$ were overweight (1). In 2002, the prevalence of overweight in 6 to 12 -y-old Swiss boys and girls was of respectively 16.6 and $19.9 \%$ (2). In the past the role of adult obesity as an independent cardiovascular risk (CVR) factor has remained controversial, because of its frequent coexistence with other CVR and metabolic disorders, such as hypertension, dyslipidemia and insulin resistance $(3,4)$. It is now well demonstrated that obesity is a significant independent predictor of CVR $(5,6)$ and/or mortality (7). CVR factors act early in life and have a major impact on the development of atherosclerosis and lifetime risk of cardiovascular disease. Atherosclerosis has been shown to have a long preclinical phase, with development of pathologic changes in arteries of children and young adults, well before clinical manifestations of the disease appear in

Received February 14, 2007; accepted March 15, 2007.

Correspondence: Yacine Aggoun, M.D., Paediatric Cardiology Unit, Department of Paediatrics, University Children's Hospital of Geneva, 6, rue Willy-Donzé 1211 Geneva 14, Switzerland; e-mail: yacine.aggoun@hcuge.ch

DOI: $10.1203 /$ pdr.0b013e31805d8a8c adults. Foetal (8) and early postnatal factors (9) may influence or program the development of atherosclerosis and its complications. The relationship between the extent of early atherosclerotic lesions in children and their blood lipid levels has also been established (10).

This programming might occur directly via an effect on vascular physiology (11) or else via the programming of CVR factors such as obesity (12). Obesity in childhood has adverse effects on adult cardiovascular health that are independent of adult weight (13). The Bogalusa Heart Study has suggested that parents contribute to their children's risk of developing the MS (14). Obesity is a well-established independent risk factor for coronary artery disease but the mechanisms that relate fat mass to vascular health are poorly understood. Excess fat, and particularly visceral fat, predispose to the major components of MS and several definitions of this syndrome have been developed for adults: the World Health Organization (WHO) based on disease processes (15), the Adult Treatment Panel III (ATPIII) (16), the European group for the Study of Insulin Resistance (EGIR), the American college of Endocrinology Task Force on the Insulin Resistance Syndrome (17) and more recently the International Diabetes Federation $(18,19)$. Following the WHO criteria, MS includes increased blood pressure, abdominal obesity, elevated triglyceride levels, low HDL (HDL), insulin resistance and microalbuminuria and it influences cardiac risk. MS exists in adults, and many of the variables appear to be present in childhood and adolescents. The prevalence of MS in children and adolescents (3\% to 4\%) (20) is lower than that reported by several studies in adults (21-24). Ornstein and Jacobson proposed a definition of the MS in children and adolescents based on ATP III criteria and cut-off values for the various features of the MS in children and adults (20). Evidence is also provided that the MS is accompanied by a thrombotic and proinflammatory state, as well as hyperuricemia (25).

\section{OBESITY BIOMARKERS OF METABOLIC SYNDROME}

Obese individuals who more commonly show features of the MS exhibit a clustering of phenotypes associated with increased cardiovascular risk. Insulin resistance is suggested to be central of this syndrome's pathogenesis and explains the

\footnotetext{
Abbreviations: BP, blood pressure; CVD, cardiovascular disease; CVR, cardiovascular risk; EPC, endothelial progenitor cells; FMD, flow mediated dilation; IMT, intima media thickness; MS, metabolic syndrome; PWV, pulse wave velocity; VCAM, vascular cell adhesion molecule
} 
association between obesity and vascular dysfunction. However, recent additions to this clustering, such as an elevation of levels of plasminogen-activator inhibitor, microalbuminaria and endothelial dysfunction cannot be clearly explained by insulin-mediated mechanisms. Moreover, obesity is associated with features of acute-phase activation and low-grade inflammation is recognized as a component of atherosclerosis (26). C-reactive protein (CRP), IL-6, fibrinogen and TNF- $\alpha$ are associated with adiposity in children $(27,28)$. Markers of systemic low-grade inflammation worsen with increasing adiposity (29). The molecular mechanism of CRP related to insulin resistance has been examined with the purpose that CRP induces the phosphorylation of jun $\mathrm{N}$-terminal kinase (JNK) and Insulin receptor substrate-1 (IRS-1) Ser307 site through a spleen tyrosine kinase (Syk) and RhoA-activation signalling pathway (30). An increased level of isoprostanes, as a measure of oxidative stress, was seen in association with greater adiposity in adolescents (27). All these factors could affect vascular function by their local and distant actions. Inter-related metabolic, biochemical and inflammatory factors associated with obesity have an effect on vascular structure and endothelial function (31) and are summarized in the Table 1. It has been hypothesized that both insulin resistance and endothelial dysfunction have a common background, possibly via inflammatory mediators released from adipose tissue (32) or even a common risk factor in the perinatal period. Foetal and early postnatal nutrition have been postulated to be the "common soil" that programmes the development of the MS thus affecting the propensity to both clinical CVD and noninsulin-dependent diabetes. Low birth weight as a result of preterm birth does not seem to be associated with endothelial dysfunction (33). However, an association between intrauterine growth retardation (IUGR) and endothelial dysfunction has been demonstrated (11). Evidence of reduced muscle uptake of glucose but normal endothelial function in men with low birth weight also suggests that programming of insulin resistance can occur independently of an effect on endothelial function (34). Many interactions between metabolism and vascular tissues contribute to major relationships between insulin resistance and endothelial function (35). Adipose tissue has become increasingly important in understanding the role of obesity in vascular disease. It produces several biologically-active cytokine-like molecules that could mediate the increased risk of CVD associated with obesity. The two most promising of such molecules for an effect on vascular function are leptin and adiponectin. The action of leptin could be mediated via receptors widely distributed on endothelial cells, to stimulate smooth muscle cell proliferation and migration, and hence impair arterial elasticity. This suggests that a high leptin concentration is a key link between obesity and vascular disease (36). Adiponectin, which acts as a regulator of MS (37), might be cardio-protective by inhibiting TNF- $\alpha$-mediated monocyte adhesion, formation of foam cells and smooth muscle cell proliferation and also by promoting blood vessel growth and endothelial NO production (38). Endothelial function is impaired in adiponectin knock-out mice, whereas forced adiponectin expression reduces atherosclerotic lesions in a mouse model of atherosclerosis (39). Hypoadiponectin has been associated with impaired endothelial function in patients with mild hypertension and type 2 diabetes and in healthy adult controls (40). There are relatively few data for human beings, especially for young individuals, that support an independent anti-atherogenic action of adiponectin. Adiponectin contributes to the maintenance of insulin sensitivity in young, nonobese individuals but does not affect the development of early endothelial dysfunction (41). Leptin, adiponectin, free fatty acids (FFA), and ghrelin are emerging biomarkers of insulin resistance (42-45); the three latest have also been implicated as biomarkers of coronary artery disease (46-48). Many prospective studies have shown that individuals with MS have a greater risk of developing type 2 diabetes and cardiovascular disease. Assessment of CVD risk and MS in children and adolescents has involved the analysis of serum or plasma biomarkers including total cholesterol (TC), triglycerides (TG), HDL cholesterol (HDL-C), insulin and Cpeptide. Lipids and lipoproteins play an important role in the development as well as in consequences of MS. The dislipidemia results in increased production of TG and secretion of very low density lipoprotein along with associated abnormalities like reduction of in HDL-C and increased density of LDL. Hypertriglyceridemia is associated with predominance of small dense LDL particles which is due to relative depletion of unesterified cholesterol, esterified cholesterol and phospholipids with either no change or an increase in LDL triglyceride. Small dense LDL is more toxic to endothelium, can transit through endothelial basement membrane easily, ad-

Table 1. Metabolic biomarkers and their roles

\begin{tabular}{lll}
\hline \multicolumn{1}{c}{ Class } & \multicolumn{1}{c}{ Members } & \multicolumn{1}{c}{ Role } \\
\hline Lipids and lipoproteins & Low density/lipoprotein particle number & Vascular injury \\
Adipokines & Leptin & \\
& Adiponectin & Modulation of insulin sensitivity \\
& Anti-inflammatory action \\
& Resistin & Impairment of glucose tolerance \\
Inflammatory markers & C-Reactive protein & Endothelial cell activation \\
& C3/ASP (Acylation Stimulating Protein) & Induction of tissue damage \\
Cytokines & Tumor Necrosis Factor $\alpha$ receptor 2 & Insulin resistance \\
& IL-6 & Atherothrombosis \\
& IL-8 & Neutrophils attraction to endothelium \\
Chemokines & Monocyte Chemotactic Protein-1 (MCP-1) & Induction of cell adhesion molecule expression \\
\hline
\end{tabular}


heres well to glycosaminoglycans, is more susceptible to oxidation and is more selectively bound to scavenger receptors on monocytes derived macrophages (49). Recently, emerging biomarkers such as apolipoprotein (apo)-AI and apo-B have been proposed as precise predictors of atherogenicity and CVD risk (50).

\section{ASSESSMENT OF THE IMPACT OF OBESITY ON CARDIOVASCULAR FUNCTION}

Obesity might also promote preclinical atherosclerotic changes via a direct effect on vascular physiology. Greater adiposity in childhood or adolescence has been associated with greater cardiovascular and all-cause mortality in adult life (51-54). Several reports now suggest that obesity impairs vascular function (55). Obese individuals show an impaired endothelial-mediated vasodilator response to increase blood flow (56) and to insulin (57). Similarly, obesity is associated with greater arterial stiffness (58-62) and visceral adiposity is particularly detrimental (63). The precise mechanism by which obesity in childhood increases CVR above that of fatness in adult life remains unexplained. One possibility is that of a prolonged exposure of arteries to the metabolic milieu associated with obesity (such as a high insulin concentration) (13). Endothelial dysfunction and arterial stiffness in young individuals who are obese is now a strong evidence from an early age. The underlying mechanism for this effect is contentious. Childhood obesity exerts its effects on coronary heart disease by way of its persistence into adulthood (64). The tools to obtain functional and morphologic characteristics of arteries in adults have been successfully used to analyze arterial function in the pediatric population. Ultrasound evaluation of morphology and mechanical properties of great elastic arteries and endothelial function of brachial artery have been used in the clinical setting to assess coronary risk in childhood obesity as well as in other high cardiovascular risk populations like heterozygous familial hypercholesterolemia (65-67), type 1 diabetes $(68,69)$ or homozygous homocystinuria (70). These advanced methods in cardiovascular imaging research detect early anatomic evidence of atherogenesis. Thickening of the intima and media of the great vessels can be visualized, mechanical properties of such vessels can be measured and endothelial function can be assessed by reactive hyperemia, after release of a tourniquet inflated above the systolic pressure to induce ischemia in the forearm, described as FMD and contribute to reveal early atherogenesis in children and adolescents. Mechanical properties measure the early sign of atherosclerosis using the state of elasticity or stiffness of the arterial wall. Arterial compliance and distensibility is determined by arterial transmural pressure and its structural components of mainly collagen and elastin. Arterial stiffness correlates closely with early atherosclerosis disease and has been well demonstrated in obese children $(58,59,61)$. Arterial stiffness can be estimated from the incremental elastic modulus independently of the pressure or indirectly from the PWV using tonometry of applanation. PWV represents the time that the pulse wave takes to travel a given distance along the vasculature and is derived from the complex interactions between the ventricular performance, the physical properties of the arterial system, and rheological characteristics of the blood (71). The faster is PWV and the greater is the arterial stiffness. Additionally, analysis of the pulse wave form by tonometry of applanation provides a noninvasive means to record local arterial blood pressure and wave reflection (72). PWV of the upper limbs was used for the first time by Toto-Moukouo et al. to evaluate mechanical properties of large arteries in adult obese hypertensive individuals. In this population, a significant positive correlation was observed between the degree of obesity and PWV independently of age, gender and level of BP (73). Increased aortic stiffness has been shown in obese adults to be more related to body fat repartition, assessed by waist circumference and visceral adiposity, than to increased BMI (74-76). Noninvasive assessment of vascular function has become a surrogate for more invasive identification of cardiovascular disease. The procedure has little risks, allows studies of large populations and serial individual follow-up over time. These approaches give an estimation of the local or regional function of the examined arterial bed. These various studies in pediatric populations indicate that endothelial dysfunction and carotid thickening found in conditions predisposing to atherosclerosis may be present at a young age $(68,69,77-80)$. However, the thickness of the arterial wall can be a matter of debate.

Indeed, a majority of studies (81-86) report an increased in carotid IMT in obese children when compared with lean controls. It was also described an association between IMT and BP $(81,83)$, and some of these studies included obese children with hypertension $(82,83)$ or with BP values significantly increased when compared with their referents (83). Furthermore, some of these obese children have a dyslipidemia. A recent publication (87) has reported the absence of significant increase of IMT in severely obese children with a mean age of $12 \mathrm{y}$ old. This result is in accordance with our previously reported findings in severe obese children with a mean age of 12.6-y-old (58). In these two studies the patients had a normal BP. This arterial phenotypic change occurs in situation of hypertension but also in situation of dyslipidemia (88). These alterations of vascular function in at-risk children could be useful markers of preclinical vascular disease and may help evaluate the risk modification by therapeutic interventions. Additionally, these methods could be a useful tool for risk stratification in children at risk, thereby permitting identification of children who would benefit most from intensified therapy. Longitudinal studies from childhood to adulthood have suggested that being obese or overweight in early life may be associated with increased atherosclerosis, including increased carotid artery IMT, as well as increased morbidity and mortality from cardiovascular causes. Juonala et al. (89) demonstrated that subjects who had been overweight or obese in youth had significantly higher carotid IMT values in adulthood compared with subjects who had been lean in youth, but subjects who had been obese in the youth but were nonobese as adults had IMT values comparable with subjects who had remained consistently nonobese. This relationship is mostly explained by significant tracking of body mass from youth to adulthood. Endothelial dysfunction is one of the 
earliest signs of increased risk for cardiovascular disease and has been shown to be predictive of cardiovascular events (90). In obese children, endothelial dysfunction is related to the severity of obesity, as well as to the degree of insulin resistance (58) and contributes to early atherogenesis during childhood because endothelial cells are important in the regulation of vasomotion, thrombosis and inflammation. Consequently, the brachial artery endothelium function measured by flowmediated endothelial-dependent vasodilatation is impaired. Other measures of the function and integrity of the endothelium include various biochemical markers such as circulating adhesion molecules (ICAM-1, VCAM-1 E-selectin), molecules that increase during endothelial damage (von Willebrand factor, soluble thrombomodulin) and circulating endothelial progenitor cells (EPC). Low circulating EPC level may thus represent a useful marker of future cardiovascular events (91). The significance of endothelial dysfunction and intima-medial thickening and their long-term consequences remain unknown. Endothelial dysfunction and alteration of the mechanical properties of the arterial wall are observed early in life in children harboring classic cardiovascular risk factors or conditions known to confer a risk of premature atherosclerosis in adults.

\section{RELATIONSHIP BETWEEN MS AND VASCULAR FUNCTION}

Obesity in children has been associated with decreased arterial elasticity $(58,60,62,84)$. Childhood obesity has been demonstrated to have predictive value for decreased arterial elasticity in adulthood (61). The association of obesity with metabolic disorders like hyperinsulinemia has been shown to decrease arterial elasticity (92) and was associated independently with carotid artery elasticity. Overweight has been related with low-grade inflammation (93). Yasmin et al. showed that CRP correlates directly with arterial stiffness (94). Subclinical inflammation characterized by elevation of CRP has been described as an early complication of childhood obesity which contributes to an later increased burden of type 2 diabetes mellitus in this population (95). Serum concentration of inflammatory biomarkers, such as CRP and also serum amyloid A (SAA), interleukine-6 (IL-6), have emerged as independent predictors of vascular incident and MS (96). Furthermore, elevation in leptin levels, a hormone that plays a key role in the regulation of appetite and body weight, has been related to impaired arterial distensibility in children (97). Increasing CRP concentration was considered as an early complication of childhood obesity in a specific population that exhibit an enhanced cardiovascular risk profile mediated by central adiposity (95). Elevated BP measured in childhood obesity is considered as an independent predictor of arterial elasticity in young adults and contributes to accelerate atherosclerosis, collagen synthesis, arterial smooth muscle hyperplasia and hypertrophy, which lead to increased arterial stiffness (13). A recent study reported an increased risk of elevated BP, high concentrations of total cholesterol, LDL cholesterol, and triglycerides; and a low concentration of HDL cholesterol in overweight Korean children and adolescents (98). An associ- ation between micro-albuminuria and insulin resistance $(99,100)$ or increased blood glucose levels $(101,102)$ has also been previously demonstrated in adults. The effect of childhood obesity and obesity-related CVR factors on glomerular and tubular protein excretion was demonstrated by the link between enhanced albuminuria and presence of the features of the MS in children (103). In the near future, a better knowledge of children obesity associated with the appropriate intervention upon obesity-related factors could lead to prevent adult obesity, the MS and CVR.

\section{PREVENTION APPROACHES}

The incidence of overweight children aged between 6 and $11 \mathrm{y}$ has more than doubled while the incidence for adolescents from age 12 to 19 has tripled between 1980 and 2000 (104). The metabolic and cardiovascular consequences of childhood obesity and their link are well demonstrated and have to be carefully considered to prevent rather than treat this disease. The relationship between obesity, metabolic syndrome and CVR and the sites of possible intervention are illustrated by the Fig. 1.

\section{SECONDARY PREVENTION}

Changes of traditional cardiovascular risk factors and vascular function may promote long-term cardiovascular benefits of treating childhood overweight and obesity. The link between improvement of vascular function and dietary weight loss has been established in adults (105-108) but has not been repeatedly associated with improved endothelial function (109,110). In obese children, combined dietary and exercise treatment improve the factors of metabolic syndrome (111113). However, this improvement is attenuated or absent when dietary treatment is used in the absence of concurrent exercise therapy (114).

Woo et al. found that in overweight and obese 9-12 y olds, 6 weeks of dietary modification alone or diet plus a supervised structured exercise programme were both associated with increased FMD. However, the changes were significantly

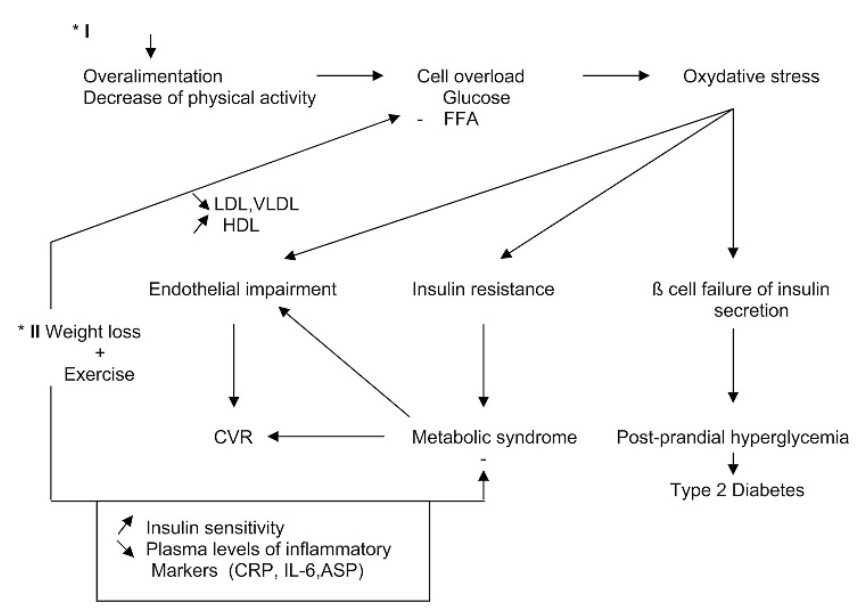

Figure 1. Illustration of the relationship between obesity, metabolic syndrome, bioactive cytokines and CVR. The sites of interventions are illustrated by the symbol (*) and characterize the primary (I) and the secondary (II) prevention of obesity. 
greater after diet plus exercise compared with diet alone. Exercise and diet continued for one year resulted in further improvement in FMD and a regression of IMT. In contrast, although some benefit continued to exist at one year, the FMD returned toward baseline in those subjects who ceased exercise. At one year, diet alone also induced a small but significant reduction in IMT. It appears that dietary therapy has a limited long-term benefit, but effectiveness of exercise alone for improving endothelial function, in the absence of dietary therapy is modest and the FMD is still relatively low when compared with the control subjects (115-117). According to the results obtained in these studies, a combination of optimal diet and exercise training may successfully restore vascular function to near normal values. It was demonstrated that exercise training (118) or medical or surgical treatment (119) reverses endothelial dysfunction associated with obesity in adults. In adults it has been demonstrated that weight loss is associated with reduction of the progression rate of carotid IMT after $4 \mathrm{y}$ but no reduction of IMT (120). In a recent study performed in obese children, it has been demonstrated that a 6-mo program of enhanced physical exercise improves the endothelial function of the radial artery, reduces IMT of the carotid artery, systolic BP and left ventricular mass (117). The length of time required to produce sustained and stable changes after intervention to improve vascular status remains unknown; however it has been showed that improvement of endothelial function was reversible within $8 \mathrm{wk}$ after cessation of training in adults and adolescents $(121,122)$.

\section{PRIMARY PREVENTION}

The serious and lifelong health complications of excess body weight suggest that providing resources for primary prevention in children is advantageous. The preschool years have been identified as a crucial time to intervene, as early childhood interventions may promote lifelong healthy behaviors before the development of unhealthy behaviors $(123,124)$. Furthermore, early childhood interventions that coincide with early adiposity rebound are considered critical to help prevent obesity later in life (125). Indeed, it has been showed that increases in BMI and the propensity of overweight and obesity follow a quadratic growth curve with the steepest increase before and during puberty (126). Children with higher baseline BMI have a steeper increase in BMI-levels over time supported by studies on tracking (127-133).

Therefore, to curb the nation's obesity epidemic, innovative approaches toward the primary prevention of obesity in young children are urgently needed. Features of this ambitious prevention program should include adapted feeding from the birth to elderly, healthy dietary habits and regular physical activity that could be expected to have effects on body composition. The information of the side effects of obesity on cardiovascular function by mass media campaigns, the participation of industries to promote or prevent various types of consumption, will facilitate a wide participation of such program. Committing resources to high-risk groups might also possibly be an effective approach. Thus, the prevention of obesity among children and adolescents might be possible.

\section{REFERENCES}

1. Kant AK, Graubard BI 2006 Secular trends in patterns of self-reported food consumption of adult Americans: NHANES 1971-1975 to NHANES 1999-2002. Am J Clin Nutr 84:1215-1223

2. Zimmermann MB, Gubeli C, Puntener C, Molinari L 2004 Detection of overweight and obesity in a national sample of 6-12-y-old Swiss children: accuracy and validity of reference values for body mass index from the US centers for Disease Control and Prevention and the International Obesity Task Force. Am J Clin Nutr 79:838-843

3. Stamler R, Stamler J, Riedlinger WF, Algera G, Roberts RH 1978 Weight and blood pressure. Findings in hypertension screening of 1 million Americans. JAMA 240:1607-1610

4. Stamler R, Ford CE, Stamler J 1991 Why do lean hypertensives have higher mortality rates than other hypertensives? Findings of the Hypertension Detection and Follow-up Program. Hypertension 17:553-564

5. Czernichow S, Mennen L, Bertrais S, Preziosi P, Hercberg S, Oppert JM 2002 Relationships between changes in weight and changes in cardiovascular risk factors in middle-aged French subjects: Effects of dieting. Int J Obes Relat Metab Disord 26:1138-1143

6. Wang TJ, Parise H, Levy D, D’Agostino RB Sr, Wolf PA, Vasan RS, Benjamin EJ 2004 Obesity and risk of new-onset atrial fibrillation. JAMA 292:2471-2477

7. McGee DL 2005 Body mass index and mortality: A meta-analysis based on person-level data from twenty-six observational studies. Ann Epidemiol 15:87-97

8. Barker DJ, Martyn CN, Osmond C, Hales CN, Fall CH 1993 Growth in utero and serum cholesterol concentrations in adult life. BMJ 307:1524-1527

9. Singhal A, Cole TJ, Fewtrell M, Deanfield J, Lucas A 2004 Is Slower Early Growth Beneficial for Long-Term Cardiovascular Health? Circulation 109:1108-1113

10. Newman WP, Freedman DS, Voors AW, Gard PD, Srinivasan SR, Cresanta JL, Williamson GD, Webber LS, Berenson GS 1986 Relation of serum lipoprotein levels and systolic blood pressure to early atherosclerosis. The Bogalusa Heart Study. N Engl J Med 314:138-144

11. Leeson CP, Whincup PH, Cook DG, Donald AE, Papacosta O, Lucas A, Deanfield JE 1997 Flow-Mediated Dilation in 9- to 11-Year-Old Children. The Influence of Intrauterine and Childhood Factors. Circulation 96:2233-2238

12. Singhal A, Farooqi I, O'Rahilly S, Cole TJ, Fewtrell M, Lucas A 2002 Early nutrition and leptin concentrations in later life. Am J Clin Nutr 75:993-999

13. Vanhala M, Vanhala P, Kumpusalo E, Halonen P, Takala J 1998 Relation between obesity from childhood to adulthood and the metabolic syndrome: population based study. BMJ 317:319

14. Chen W, Srinivasan SR, Elkasabany A, Berenson GS 1999 The association of cardiovascular risk factor clustering related to insulin resistance syndrome (Syndrome $\mathrm{X}$ ) between young parents and their offspring: the Bogalusa Heart Study. Atherosclerosis 145:197-205

15. World Health Organization Definition, diagnosis and classification of diabetes mellitus and its complications; Part 1: diagnosis and classification of diabetes mellitus. Geneva: department of Non-communicable Disease Surveillance 1999

16. Expert Panel on Detection, Evaluation, and Treatment of High Blood Cholesterol in Adults 2001 Executive summary of the third report of The National Cholesterol Education Programm (NCEP) Expert Panel on Detection, Evaluation, And Treatment of High Blood Cholesterol In Adults (Adult Treatment Panel III). JAMA 285:2486-2497

17. American College of Endocrinology Task Force on the Insulin Resistance Syndrome 2003 American College of Endocrinology Position Statement on the Insulin Resistance Syndrome Endocr Pract 9:236-239

18. Zimmet PZ, Alberti KG, Shaw JE 2005 Mainstreaming the metabolic syndrome: a definitive definition. Med J Aust 183:175-176

19. Magliano DJ, Shaw JE, Zimmet PZ 2006 How to best define the metabolic syndrome. Ann Med 38:34-41

20. Ornstein RM, Jacobson MS 2006 Supersize teens: The metabolic syndrome. Adolesc Med Clin 17:565-587

21. Isomaa B, Almgren P, Tuomi T, Forsen B, Lahti K, Nissen M, Taskinen MR, Groop L 2001 Cardiovascular morbidity and mortality associated with the metabolic syndrome. Diabetes Care 24:683-689

22. Ford ES, Giles WH, Dietz WH 2002 Prevalence of the metabolic syndrome among US adults: findings from the third National Health and Nutrition Examination Survey. JAMA 287:356-359

23. Laaksonen DE, Lakka HM, Niskanen LK, Kaplan GA, Salonen JT, Lakka TA 2002 Metabolic syndrome and development of diabetes mellitus: application and validation of recently suggested definitions of the metabolic syndrome in a prospective cohort study. Am J Epidemiol 156:1070-1077

24. Meigs JB, Wilson PW, David NM, D'Agostino RB Sr, Williams K, Haffner SM 2003 Prevalence and characteristics of the metabolic syndrome in the San Antonio Heart and Framingham Offspring Studies. Diabetes 52:2160-2167

25. Hauner H 2002 Insulin resistance, and the metabolic syndrome-a challenge of the new millennium. Eur J Clin Nutr Suppl 56 Suppl 1:S25-S29

26. Pearson TA, Mensah GA, Alexander RW, Anderson JL, Cannon RO, Criqui M, Fadl YY, Fortmann SP, Hong Y, Myers GL, Rifai N, Smith SC, Taubert K, Tracy RP, Vinicor F 2003 Markers of inflammation and cardiovascular disease: Application to clinical and public health practice. A statement for healthcare professionals for the Centers for Disease Control and Prevention and the American Heart Association. Circulation 107:499-511

27. Sinaiko AR, Steinberger J, Moran A, Prineas RJ, Vessby B, Basu S, Tracy R, Jacobs DR Jr 2005 Relation of Body Mass Index and Insulin Resistance to Cardiovascular Risk Factors, Inflammatory Factors, and Oxidative Stress During Adolescence. Circulation 111:1985-1991 
28. Halle M, Korsten-Reck U, Wolfarth B, Berg A 2004 Low-grade systemic inflammation in overweight children: impact of physical fitness Exerc Immunol Rev 10:66-74

29. Weiss R, Caprio S 2005 The metabolic consequences of childhood obesity. Best Pract Res Clin Endocrinol Metab 19:405-419

30. Xu JW, Morita I, Ikeda K, Miki T, Yamori Y 2007 C-reactive protein suppresses insulin signaling in endothelial cells. Role of Syk tyrosine kinase. Mol Endocrinol 21:564-573

31. Kapiotis S, Holzer G, Schaller G, Haumer M, Widhalm H, Weghuber D, Jilma B, Roggla G, Wolzt M, Widhalm K, Wagner OF 2006 A proinflammatory state is detectable in obese children and is accompanied by functional and morphological vascular changes. Arterioscler Thromb Vasc Biol 26:2541-2546

32. Yudkin JS 2003 Adipose tissue, insulin action and vascular disease: inflammatory signals. Int J Obes Relat Metab Disord 27:S25-S28

33. Singhal A, Kattenhorn M, Cole TJ, Deanfield J, Lucas A 2001 Preterm birth, vascular function, and risk factors for atherosclerosis. Lancet 358:1159-1160

34. Hermann TS, Rask-Madsen C, Ihlemann N, Domínguez H, Jensen CB, Storgaard H, Vaag AA, Kober L, Torp-Pedersen C 2003 Normal Insulin-Stimulated Endothelial Function and Impaired Insulin-Stimulated Muscle Glucose Uptake in Young Adults with Low Birth Weight. J Clin Endocrinol Metab 88:1252-1257

35. Kim JA, Montagnani M, Koh KK, Quon MJ 2006 Reciprocal Relationships Between Insulin Resistance and Endothelial Dysfunction Molecular and Pathophysiological Mechanisms. Circulation 113:1888-1904

36. Safar ME, Czernichow S, Blacher J 2006 Obesity, arterial stiffness, and cardiovascular risk. J Am Soc Nephrol 17:S109-S111

37. Whitehead JP, Richards AA, Hickman IJ, Macdonald GA, Prins JB 2006 Adiponectin - a key adipokine in the metabolic syndrome. Diabetes Obes Metab $8: 264-280$

38. Ekmekci H, Ekmekci OB 2006 The Role of Adiponectin in Atherosclerosis and Thrombosis. Clin Appl Thromb Hemost 12:163-168

39. Okamoto Y, Kihara S, Ouchi N, Nishida M, Arita Y, Kumada M, Ohashi K, Sakai N, Shimomura I, Kobayashi H, Terasaka N, Inaba T, Funahashi T, Matsuzawa Y 2002 Adiponectin reduces atherosclerosis in apolipoprotein E-deficient mice. Circulation 106:2767-2770

40. Tan KC, Xu A, Chow WS, Lam MC, Ai VH, Tam SC, Lam KS 2004 Hypoadiponectinemia is associated with impaired endothelium-dependent vasodilation. J Clin Endocrinol Metab 89:765-769

41. Singhal A, Jamieson N, Fewtrell M, Deanfield J, Lucas A, Sattar N 2005 Adiponectin predicts insulin resistance but not endothelial function in young, healthy adolescents. J Clin Endocrinol Metab 90:4615-4621

42. Silha JV, Krsek M, Skrha JV, Sucharda P, Nyomba BL, Murphy LJ 2003 Plasma resistin, adiponectin and leptin levels in lean and obese subjects: correlations with insulin resistance. Eur J Endocrinol 149:331-335

43. Trujillo ME, Scherer PE 2005 Adiponectin-Journey from an adipocyte secretory protein to biomarker of the metabolic syndrome. J Intern Med 257:167-175

44. Asakawa A, Inui A, Kaga T, Katsuura G, Fujimiya M, Fujino MA, Kasuga M 2003 Antagonism of ghrelin receptor reduces food intake and body weight gain in mice. Gut 52:947-952

45. de Jongh RT, Serne EH, Ijzerman RG, de Vries G, Stehouwer CD 2004 Free fatty acid levels modulate microvascular function: relevance for obesity-associated insulin resistance, hypertension, and microangiopathy. Diabetes 53:2873-2882

46. Ouchi N, Kihara S, Arita Y, Maeda K, Kuriyama H, Okamoto Y, Hotta K, Nishida M, Takahashi M, Nakamura T, Yamashita S, Funahashi T, Matsuzawa Y 1999 Novel modulator for endothelial adhesion molecules: adipocyte-derived plasma protein adiponectin. Circulation 100:2473-2476

47. Katugampola SD, Maguire JJ, Kuc RE, Wiley KE, Davenport AP 2002 Discovery of recently adopted orphan receptors for apelin, urotensin II, and ghrelin identified using novel radioligands and functional role in the human cardiovascular system. Can J Physiol Pharmacol 80:369-374

48. Matsuzawa Y, Shimomura I, Nakamura T, Keno Y, Kotani K, Tokunaga K 1995 Pathophysiology and pathogenesis of visceral fat obesity. Obes Res. 3:187S-194S

49. Packard CJ 1996 LDL subfractions and atherogenicity: an hypothesis from the university of Glassgow. Curr Med Res Opin 13:379-390

50. Mansoub S, Khum M, Adeli K 2006 Gap analysis of pediatric reference intervals for risk biomarkers of cardiovascular disease and the metabolic syndrome. Clin Biochem 39:569-587

51. Hanson P, Schumaker P, Debugne T, Clerin M 1992 Evaluation of somatic and autonomic small fibers neuropathy in diabetes. Am J Phys Med Rehabil 71:44-47

52. Vinik AI, Holland MT, Le Beau JM, Liuzzi FJ, Stansberry KB, Colen LB 1992 Diabetic neuropathies. Diabetes Care 15:1926-1975

53. McArthur JC, Stocks EA, Hauer P, Cornblath DR, Griffin JW 1998 Epidermal nerve fiber density: normative reference range and diagnostic efficiency. Arch Neurol 55:1513-1520

54. Hirai A, Yasuda H, Joko M, Maeda T, Kikkawa R 2000 Evaluation of diabetic neuropathy through the quantitation of cutaneous nerves. J Neurol Sci 172:55-62

55. Singhal A 2005 Endothelial dysfunction: role in obesity-related disorders and the early origins of CVD. Proc Nutr Soc 64:15-22

56. Arcaro G, Zamboni M, Rossi L, Turcato E, Covi G, Armellini F, Bosello O, Lechi A 1999 Body fat distribution predicts the degree of endothelial dysfunction in uncomplicated obesity. Int J Obes Relat Metab Disord 23:936-942

57. Westerbacka J, Vehkavaara S, Bergholm R, Wilkinson I, Cockcroft J, Yki-Jarvinen H 1999 Marked resistance of the ability of insulin to decrease arterial stiffness characterizes human obesity. Diabetes 48:821-827

58. Tounian P, Aggoun Y, Dubern B, Varille V, Guy-Grand B, Sidi D, Girardet JP, Bonnet D 2001 Presence of increased stiffness of the common carotid artery and endothelial dysfunction in severely obese children: a prospective study. Lancet 358:1400-1404

59. Iannuzzi A, Licenziati MR, Acampora C, Renis M, Agrusta M, Romano L, Valerio G, Panico S, Trevisan M 2006 Carotid artery stiffness in obese children with the metabolic syndrome. Am J Cardiol 97:528-531

60. Zebekakis PE, Nawrot T, Thijs L, Balkestein EJ, van der Heijden-Spek J, Van Bortel LM, Struijker-Boudier HA, Safar ME, Staessen JA 2005 Obesity is associated with increased arterial stiffness from adolescence until old age. J Hypertens 23:1839-1846

61. Juonala M, Jarvisalo MJ, Maki-Torkko N, Kahonen M, Viikari JS, Raitakari OT 2005 Risk factors identified in childhood and decreased carotid artery elasticity in adulthood: the Cardiovascular Risk in Young Finns Study. Circulation 112:14861493

62. Levent E, Goksen D, Ozyurek AR, Darcan S, Mahmut C, Coker M, Guven H, Parlar A 2002 Stiffness of the abdominal aorta in obese children. J Pediat Endocrinol Metab 15:405-409

63. Resnick LM, Militianu D, Cunnings AJ, Pipe JG, Evelhoch JL, Soulen RL 1997 Direct magnetic resonance determination of aortic distensibility in essential hypertension: relation to age, abdominal visceral fat, and in situ intracellular free magnesium. Hypertension 30:654-659

64. Freedman DS, Khan LK, Dietz WH, Srinivasan SR, Berenson GS 2001 Relationship of childhood obesity to coronary heart disease risk factors in adulthood: the Bogulusa Heart study. Pediatrics 108:712-718

65. Celermajer DS, Sorensen KE, Gooch VM, Spiegelhalter DJ, Miller OI, Sullivan ID, Lloyd JK, Deanfield JE 1992 Non-invasive detection of endothelial dysfunction in children and adults at risk of atherosclerosis. Lancet 340:1111-1115

66. Sorensen KE, Celermajer DS, Georgakopoulos D, Hatcher G, Betteridge DJ, Deanfield JE 1994 Impairment of endothelium-dependent dilation is an early event in children with familial hypercholesterolemia and is related to the lipoprotein(a) level. J Clin Invest 93:50-55

67. Aggoun Y, Bonnet D, Sidi D, Girardet JP, Brucker E, Polak M, Safar ME, Levy BI 2000 Arterial mechanical changes in children with familial hypercholesterolemia. Arterioscler Thromb Vasc Biol 20:2070-2075

68. Jarvisalo MJ, Raitakari M, Toikka JO, Putto-Laurila A, Rontu R, Laine S, Lehtimaki T, Ronnemaa T, Viikari J, Raitakari OT 2004 Endothelial dysfunction and increased arterial intima-media thickness in children with type 1 diabetes. Circulation 109:1750-1755

69. Singh TP, Groehn H, Kazmers A 2003 Vascular function and carotid intimalmedial thickness in children with insulin-dependent diabetes mellitus. J Am Coll Cardiol 41:661-665

70. Celermajer DS, Sorensen K, Ryalls M, Robinson J, Thomas O, Leonard JV, Deanfield JE 1993 Impaired endothelial function occurs in the systemic arteries of children with homozygous homocystinuria but not in their heterozygous parents. J Am Coll Cardiol 22:854-858

71. Davies JI, Struthers AD 2003 Pulse wave analysis and pulse wave velocity: a critical review of their strengths and weaknesses. J Hypertens 21:463-472

72. Chen CH, Nevo E, Fetics B, Pak PH, Yin FC, Maughan WL, Kass DA 1997 Estimation of central aortic pressure waveform by mathematical transformation of radial tonometry pressure. Validation of generalized transfer function. Circulation 95:1827-1836

73. Toto-Moukouo JJ, Achimatos A, Asmar RG, Hugues CJ, Safar ME 1986 Pulse wave velocity in patients with obesity and hypertension. Am Heart J 112:136-140

74. Sutton-Tyrrell K, Newman A, Simonsick EM, Havlik R, Pahor M, Lakatta E, Spurgeon H, Vaitkevicius P 2001 Aortic stiffness is associated with visceral adiposity in older adults enrolled in the study of health, aging, and body composition. Hypertension 38:429-433

75. Wildman RP, Mackey RH, Bostom A, Thompson T, Sutton-Tyrell K 2003 Measures of obesity are associated with vascular stiffness in young and older adults. Hypertension 42:468-473

76. Czernichow S, Bertrais S, Oppert JM, Galan P, Blacher J, Ducimetiere P, Hercberg $S$, Zureik M 2005 Body composition and fat repartition in relation to structure and function of large arteries in middle-aged adults (the SU.VI.MAX. study). Int J Obes 29:826-832

77. Pomilio M, Mohn A, Verrotti A, Chiarelli F 2002 Endothelial dysfunction in children with type 1 diabetes mellitus. J Pediatr Endocrinol Metab 15:343-361

78. Romano M, Pomilio M, Vigneri S, Falco A, Chiesa PL, Chiarelli F, Davi G 2001 Endothelial perturbation in children and adolescents with type 1 diabetes: association with markers of the inflammatory reaction. Diabetes Care 24:1674-1678

79. Jarvisalo MJ, Jartti L, Nanto-Salonen K, Irjala K, Ronnemaa T, Hartiala JJ, Celermajer DS, Raitakari OT 2001 Increased aortic intima-media thickness: a marker of preclinical atherosclerosis in high-risk children. Circulation 104:29432947

80. Pena AS, Wiltshire E, Gent R, Hirte C, Couper J 2004 Folic acid improves endothelial function in children and adolescents with type 1 diabetes. J Pediat 144:500-504

81. Reinehr T, Kiess W, de Sousa G, Stoffel-Wagner B, Wunsch R 2006 Intima media thickness in childhood obesity. Relations to inflammatory marker, glucose metabolism, and blood pressure. Metabolism 55:113-118

82. Stabouli S, Kotsis V, Papamichael C, Constantopoulos A, Zakopoulos N 2005 Adolescent obesity is associated with high ambulatory blood pressure and increased carotid intimal-medial thickness. J Pediatr 147:651-656

83. Zhu W, Huang X, He J, Li M, Neubauer H 2005 Arterial intima-media thickening and endothelial dysfunction in obese Chinese children. Eur J Pediatr 164:337-344

84. Iannuzzi A, Licenziati MR, Acampora C, Salvatore V, Auriemma L, Romano ML, Panico S, Rubba P, Trevisan M 2004 Increased carotid intima-media thickness and stiffness in obese children. Diabetes Care 27:2506-2508 
85. Woo KS, Chook P, Yu CW, Sung RY, Qiao M, Leung SS, Lam CW, Metreweli C, Celermajer DS 2004 Overweight in children is associated with arterial endothelial dysfunction and intima-media thickening. Int J Obes Relat Metab Disord 28:852857

86. Mangge H, Schauenstein K, Stroedter L, Griesl A, Maerz W, Borkenstein M 2004 Low grade inflammation in juvenile obesity and type 1 diabetes associated with early signs of atherosclerosis. Exp Clin Endocrinol Diabetes 112:378-382

87. Di Salvo G, Pacileo G, Del Giudice EM, Natale F, Limongelli G, Verrengia M, Rea A, Fratta F, Castaldi B, D’Andrea A, Calabro P, Miele T, Coppola F, Russo MG, Caso P, Perrone L, Calabro R 2006 Abnormal myocardial deformation properties in obese, non-hypertensive children: an ambulatory blood pressure monitoring, standard echocardiographic, and strain rate imaging study. Eur Heart J 27:2689_ 2695

88. Wunsch R, de Sousa G, Reinehr T 2005 Intima media thickness in obesity: relation to hypertension and dyslipidemia. Arch Dis Child 90:1097

89. Juonala M, Raitakari M, Viikari JS, Raitakari OT 2006 Obesity in youth is not an independent predictor of carotid IMT in adulthood. The Cardiovascular Risk in Young Finns Study. Atherosclerosis 185:388-393

90. Poredos P 2002 Endothelial dysfunction and cardiovascular disease. Pathophysiol Haemost Thromb 32:274-277

91. Constans J, Conri C 2006 Circulating markers of endothelial function in cardiovascular disease. Clin Chim Acta 368:33-47

92. Salomaa V, Riley W, Kark JD, Nardo C, Folsom AR 1995 Non-insulin-dependent diabetes mellitus and fasting glucose and insulin concentrations are associated with arterial stiffness indexes: the ARIC Study: Atherosclerosis Risk in Communities Study. Circulation 91:1432-1443

93. Yudkin JS, Stehouwer CD, Emeis JJ, Coppack SW 1999 C-reactive protein in healthy subjects: associations with obesity, insulin resistance, and endothelial dysfunction: a potential role for cytokines originating from adipose tissue? Arterioscler Thromb Vasc Biol 19:972-978

94. Yasmin, McEniery CM, Wallace S, Mackenzie IS, Cockcroft JR, Wilkinson IB 2004 C-reactive protein is associated with arterial stiffness in apparently healthy individuals. Arterioscler Thromb Vasc Biol 24:969-974

95. Retnakaran R, Hanley AJ, Connelly PW, Harris SB, Zinman B 2006 Elevated C-reactive protein in Native Canadian children: an ominous early complication of childhood obesity. Diabetes Obes Metab 8:483-491

96. Libby P, Ridker PM, Maseri A 2002 Inflammation and atherosclerosis. Circulation 105:1135-1143

97. Singhal A, Farooqi IS, Cole TJ, O'Rahilly S, Fewtrell M, Kattenhorn M, Lucas A, Deanfield J 2002 Influence of leptin on arterial distensibility: a novel link between obesity and cardiovascular disease? Circulation 106:1919-1924

98. Kim HM, Park J, Kim HS, Kim DH, Park SH 2006 Obesity and Cardiovascular Risk Factors in Korean Children and Adolescents Aged 10-18 Years from the Korean National Health and Nutrition Examination Survey, 1998 and 2001. Am J Epidemiol 164:787-793

99. Kuusisto J, Mykkanen L, Pyorala K, Laakso M 1995 Hyperinsulinemic microalbuminuria: a new risk indicator for coronary heart disease. Circulation 91:831-837

100. Mykkanen L, Zaccaro DJ, Wagenknecht LE, Robbins DC, Gabriel M, Haffner SM 1998 Microalbuminuria is associated with insulin resistance in nondiabetic subjects - the insulin resistance atherosclerosis study. Diabetes 47:793-800

101. Hiratsuka N, Shiba K, Nishida K, Iizima S, Kimura M, Kobayashi S 1998 Analysis of urinary albumin, transferrin, N-acetyl-beta-D-glucosaminidase and beta-2microglobulin in patients with impaired glucose tolerance. J Clin Lab Anal 12:351-355

102. Meigs JB, D'Agostino RB Sr, Nathan DM, Rifai N, Wilson PW, Framingham Offspring Study 2002 Longitudinal association of glycemia and microalbuminuria: the Framingham Offspring Study. Diabetes Care 25:977-983

103. Csernus K, Lanyi E, Erhardt E, Molnar D 2005 Effect of childhood obesity and obesity-related cardiovascular risk factors on glomerular and tubular protein excretion. Eur J Pediatr 164:44-49

104. Harper MG 2006 Childhood obesity: strategies for prevention. Fam Community Health 29:288-298

105. Tuomilehto J, Lindstrom J, Eriksson JG, Valle TT, Hamalainen H, Ilanne-Parikka P, Keinanen-Kiukaanniemi S, Laakso M, Louheranta A, Rastas M, Salminen V, Uusitupa M Finnish Diabetes Prevention Study Group 2001 Prevention of type 2 diabetes mellitus by changes in lifestyle among subjects with impaired glucose tolerance. N Engl J Med 344:1343-1350

106. Knowler WC, Barrett-Connor E, Fowler SE, Hamman RF, Lachin JM, Walker EA, Nathan DM Diabetes Prevention Program Research Group 2002 Reduction in the incidence of type 2 diabetes with lifestyle intervention or metformin. N Engl J Med 346:393-403.

107. Dattilo AM, Kris-Etherton PM 1992 Effects of weight reduction on blood lipids and lipoproteins: a meta-analysis. Am J Clin Nutr 56:320-328

108. Stevens VJ, Obarzanek E, Cook NR, Lee IM, Appel LJ, Smith West D, Milas NC, Mattfeldt-Beman M, Belden L, Bragg C, Millstone M, Raczynski J, Brewer A,
Singh B, Cohen J Trials for the Hypertension Prevention Research Group 2001 Long-term weight loss and changes in blood pressure: results of the Trials of Hypertension Prevention, phase II. Ann Intern Med 134:1-11

109. Raitakari M, Ilvonen T, Ahotupa M, Lehtimaki T, Harmoinen A, Suominen P, Elo J, Hartiala J, Raitakari OT 2004 Weight reduction with very-low-caloric diet and endothelial function in overweight adults: role of plasma glucose. Arterioscler Thromb Vasc Biol 24:124-128

110. Dengel DR, Kelly AS, Olson TP, Kaiser DR, Dengel JL, Bank AJ 2006 Effects of weight loss on insulin sensitivity and arterial stiffness in overweight adults. Metabolism 55:907-911

111. Kirk S, Zeller M, Claytor R, Santangelo M, Khoury PR, Daniels SR 2005 The relationship of health outcomes to improvement in BMI in children and adolescents. Obes Res 13:876-882

112. Wabitsch M, Hauner H, Heinze E, Muche R, Bockmann A, Parthon W, Mayer H, Teller W 1994 Body-fat distribution and changes in the atherogenic riskfactor profile in obese adolescent girls during weight reduction. Am J Clin Nutr 60:54-60

113. Reinehr T, Andler W 2004 Changes in the atherogenic risk factor profile according to degree of weight loss. Arch Dis Child 89:419-422

114. Sung RY, Yu CW, Chang SK, Mo SW, Woo KS, Lam CW 2002 Effects of dietary intervention and strength training on blood lipid level in obese children. Arch Dis Child 86:407-410

115. Watts K, Beye P, Siafarikas A, O’Driscoll G, Jones TW, Davis EA, Green DJ 2004 Effects of exercise training on vascular function in obese children. J Pediat 144:620-625

116. Watts K, Beye P, Siafarikas A, Davis EA, Jones TW, O’Driscoll G, Green DJ 2004 Exercise training normalizes vascular dysfunction and improves central adiposity in obese adolescents. J Am Coll Cardiol 43:1823-1827

117. Meyer AA, Kundt G, Lenschow U, Schuff-Werner P, Kienast W 2006 Improvement of early vascular changes and cardiovascular risk factors in obese children after a six-month exercise program. J Am Coll Cardiol 48:1865-1870

118. Williams IL, Chowienczyk PJ, Wheatcroft SB, Patel AG, Sherwood RA, Momin A, Shah AM, Kearney MT 2005 Endothelial function and weight loss in obese humans. Obes Surg 15:1055-1060

119. Gokce N, Vita JA, McDonnell M, Forse AR, Istfan N, Stoeckl M, Lipinska I, Keaney JF Jr, Apovian CM 2005 Effect of medical and surgical weight loss on endothelial vasomotor function in obese patients. Am J Cardiol 95:266-268

120. Karason K, Wikstrand J, Sojostrom L, Wendelhag I 1999 Weight loss and progression of early atherosclerosis in the carotid artery: a four-year controlled study of obese subjects. Int J Obes Relat Metab Disord 23:948-956

121. Kelly AS, Wetzsteon RJ, Kaiser DR, Steinberger J, Bank AJ, Dengel DR 2004 Inflammation, insulin, and endothelial function in overweight children and adolescents: the role of exercise. J Pediatr 145:731-736

122. Woo KS, Chook P, Yu CW, Sung RY, Qiao M, Leung SS, Lam CW, Metreweli C, Celermajer DS 2004 Effect of diet and exercise on obesity-related vascular dysfunction in children. Circulation 109:1981-1986

123. Schmitz MK, Jeffery RW 2000 Public health interventions for the prevention and treatment of obesity. Med Clin North Am 84:491-512

124. Borra ST, Schwartz NE, Spain CG, Natchipolsky MM 1995 Food, physical activity and fun: inspiring America's kids to more healthful lifestyles. J Am Diet Assoc 95:816-818

125. Ebbeling CB, Pawlak DB, Ludwig DS 2002 Childhood obesity: public-health crisis, common sense cure. Lancet 360:473-482

126. Rzehak P, Heinrich J 2006 Development of relative weight, overweight and obesity from childhood to young adulthood. A longitudinal analysis of individual change of height and weight. Eur J Epidemiol 21:661-672

127. Eriksson J, Forsen T, Osmond C, Barker D 2003 Obesity from cradle to grave. Int J Obes Relat Metab Disord 27:722-727

128. Wang Y, Ge K, Popkin BM 2000 Tracking of body mass index from childhood to adolescence: a 6-y follow-up study in China. Am J Clin Nutr 72:1018-1024

129. Trudeau F, Shephard RJ, Arsenault F, Laurencelle L 2001 Changes in adiposity and body mass index from late childhood to adult life in the Trois-Rivieres study. Am J Hum Biol 13:349-355

130. Gordon-Larsen P, Adair LS, Nelson MC, Popkin BM 2004 Five-year obesity incidence in the transition period between adolescence and adulthood: the National Longitudinal Study of Adolescent Health. Am J Clin Nutr 80:569-575

131. Kemper HC, Post GB, Twisk JW, van Mechelen W 1999 Lifestyle and obesity in adolescence and young adulthood: results from the Amsterdam Growth And Health Longitudinal Study (AGAHLS). Int J Obes Relat Metab Disord 23:S34-S40

132. Casey VA, Dwyer JT, Coleman KA, Valadian I 1992 Body mass index from childhood to middle age: a 50-y follow-up. Am J Clin Nutr 56:14-18

133. Whitaker RC, Wright JA, Pepe MS, Seidel KD, Dietz WH 1997 Predicting obesity in young adulthood from childhood and parental obesity. N Engl J Med 337:869873 